\title{
Quality assurance policies and implementation in nursing and midwifery training colleges in Ghana
}

\author{
Philip Anyelba Tankpara ${ }^{1}$, Dickson Adom ${ }^{2}$, Joe Adu-Agyem ${ }^{3}$ \\ ${ }^{1}$ Nursing Training College, Upper West Region, Jirapa, Ghana \\ ${ }^{2,3}$ Department of Educational Innovations in Science and Technology, Kwame Nkrumah University of Science and \\ Technology, Ghana
}

\begin{tabular}{l} 
Article Info \\
\hline Article history: \\
Received Sep 11, 2020 \\
Revised Mar 23, 2021 \\
Accepted Apr 10, 2021 \\
\hline
\end{tabular}

\section{Keywords:}

Health delivery

Higher education

Midwifery and nursing

Participatory governance

Quality assurance

\begin{abstract}
The study assessed internal quality assurance (QA) systems in health training institutions in the Upper West Region. The study adopted the cross-section analytical design with a sample size of 272 (67 health tutors and 205 final year nursing students) using systematic and purposive sampling techniques. Data for the study were collected with a questionnaire and analyzed using SPSS and Stata. The study revealed that the majority ( 5 of 7$)$ of nursing and midwifery colleges (NMTCs) in the Upper West Region have no quality assurance policy available, $65.7 \%$ of tutors indicated their institutions had quality assurance units/committees however these committees are inactive the total level of QA practices/implementation rate was low among colleges in the region. The study also revealed a lack of participatory governance and the existence of a poor communication system between staff and heads. The study contended that there is a need for heads (principals) of NMTCs in the Upper West region in Ghana should ensure the formation and functioning of QA units in their various institutions. These units should be empowered and allowed by heads to function as per recommendations by the regulatory bodies to support and to ensure quality training of nurses and midwives.
\end{abstract}

This is an open access article under the CC BY-SA license.

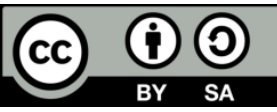

\section{Corresponding Author:}

Dickson Adom

Department of Educational Innovations in Science and Technology

Kwame Nkrumah University of Science and Technology

PMB University Post Office, Kumasi-Ghana

Email: dickson.adom@knust.edu.gh; adomdick2@gmail.com

\section{INTRODUCTION}

Quality in health care delivery has become a global concern most especially in Ghana. According to Materu [1] about 740 million people are living in the African sub-region with a variety of 200 public universities coupled with a quick increasing range of private teaching institutions. He iterated that Sub-Saharan Africa (SSA) has the lowest tertiary gross enrollment magnitude relation within the world (about 5\%) and is currently paying bigger attention to problems with quality at the tertiary level. WHO [2] noted that nursing and midwifery education is the base of a certified and able nursing and midwifery force and so the standard of nursing and midwifery education and coaching is a vital manner of building up health systems. Thus, the World Health Organization suggested that by establishing standards for skilled education, reassuring quality academic processes and establishments, and accrediting establishments providing academic programmers for an initial, specialist, and advanced skilled education, quality can be maintained in nursing and midwifery education. The capacity of human resources for health in terms of magnitude and quality has been recognized as a beneficial constituent of strengthening health care systems to achieve the targets of the millennium development goals 
four, five, and six (i.e., to reduce child mortality; to improve maternal health and to combat HIV/AIDS, malaria and other diseases respectively).

The health workforce plays an indispensable role in building up the health system. However, these men and women should be ample in number, competent, and actuated [2]. In ensuring quality, nursing, and midwifery academic establishments, nursing councils, and authoritative bodies can play a significant role in producing qualified graduates [3]. Educational establishments ought to build up their approaches and components to cling to government strategies, and effectively actualize quality assurance structures with ongoing inspection and evaluation [4]-[6]. The nursing and midwifery administrations must give criticism to instructive organizations to progress and work as a team with them to create the ideal nursing and midwifery workforce. Utuka [7] noted that higher education institutions in Ghana rarely have evidence of policies on quality assurance procedures.

The implementation of QA policy by higher education institutions, specifically nursing and midwifery colleges (NMTCs), involves the provision of services that meet expectations of all key stakeholders, particularly the labor markets and the students who are direct beneficiaries [5], [8]. Tertiary institutions recognized by National Accreditation Board (NAB) of Ghana are required to set up internal quality assurance unit (IQAU) within a maximum of five years from the date of first accreditation [6], [7]. Per the NAB directive, the existence of useful IQAU could be a key marker in evaluating the execution of an institution towards organization re-accreditation and the grant of presidential approval. This unit, like other quality assurance bodies globally, is expected to conduct occasional surveys to evaluate the degree to which objectives are met inside the system of the rules, and whether the strategies for instructional delivery and learning, the offices, and the budgetary and human resource for the conveyance of the educational program bolster the objectives [6].

The Nursing/Midwifery Training Colleges in Ghana are under three quality supervision bodies and a University for the ensuring of quality. These include the National Accreditation Board (NAB), Nursing and Midwifery Council (NMC), Health Training Institution Secretariat (HTIS) under the Ministry of Health (MoH), and Kwame Nkrumah University of Science and Technology (KNUST) which all public Nursing/Midwifery Training College is affiliated to for the award of diploma in nursing for the graduates. Despite all these mechanisms, Böhmig [9] indicated that nursing students from the NMTCs and universities, experience a gap between the theoretical teaching syllabus and the practical working condition in the hospital. He again indicated that there is also a lack of supervision at the clinical site due to a lack of clinical tutors (also known as preceptors). On the aspect of affiliation, Alabi, et al. [8] postulated that Private Institutions in Ghana also complained about the effectiveness of affiliation as a mentoring process which results in negative consequential effects. Patients are not getting the specified care that is required for them from nurses [10].

Adu-Gyamfi and Brenya [10] also discovered that the nursing profession in Ghana presently has become a refuge amid the joblessness system for the populace since one is secured of his/her work after nursing school. Also, instruction for nurses in Ghana in the years ensuing was troubled with difficulties for tutors and textbooks. These textbooks when accessible were obsolete and students did not have the financial strength to acquire them. Also, checks on the national accreditation board, Ghana [11] indicated that only 16 of all the public nursing and midwifery training colleges in Ghana have active accreditation and from which only two (Midwifery Training College-Tumu and Nursing Training College-Lawra) out of the seven colleges in the Upper West Region were part [11]. Therefore, this study sought to bridge these gaps by assessing the state of QA policies as well as their implementation in nursing and midwifery training colleges (NMTCs) in the Upper West Region of Ghana. It will also add to the scanty literature of quality assurance in NMTCs in Ghana. The research questions that pivoted the study were: 1) What is the evidence of quality assurance policies in NMTCs meant to ensure the quality of training in the Upper West Region of Ghana? 2) How are quality assurance policies implemented in NMTCs in the Upper West Region of Ghana?

European Association for Quality Assurance in Higher Education Area [12] asserted that policies and processes for quality assurance in an organization are the primary mainstays of an intelligible institutional quality confirmation framework that shapes a cycle for perpetual advancement and adds to the responsibility of the foundation. The policy statement for advanced tuition institutions in the Norms and guidelines for internal quality assurance within advanced tuition institutions are expected to include the relationship between instructions and research within the establishment; the institution's procedure for value and benchmarks; the organization of the quality assurance system; the obligations of offices, schools, faculties, and other units and people for the affirmation of quality; students role in quality assurance; and how the approach is actualized, observed and changed [13]. New Zealand has detailed approaches with respect to quality assurance executives and that these arrangements are expansive and spread all parts of their frameworks. The approaches are archived as an institutional quality assurance manual which is exposed to a consistent survey. The same cannot be said of Ghana because higher education institutions in Ghana rarely have evidence of policies on quality assurance procedures and the documentation of these in manuals [7]. 
Seniwoliba [14] assumed that aside from the principles set aside by the quality assurance bodies for the assurance of quality; each organization has its internal policies and mechanisms for ensuring the fulfillment of its mandate as a credible School. Augmentation of quality in advance learning demands qualified and highly motivated staff members who are committed to quality outcomes [15]. In addition, it can be achieved by ensuring that workers are involved in quality assurance activities through effective and reasonable top-down and bottom-up communication channels as well as rigorous labor enlistment processes, development, and stimulus systems. There should also be an administrative structure that has the responsibility for carrying out the policies of the organization by its vision, mission, goal, and objectives [4]. The NMEI principal ought to have a rudimentary educational experience in nursing or midwifery and that the management of the Nursing and Midwifery Education Institution (NMEI) is implemented, supervised, and valued by committees. The administrative staff should be adequate and competent in their work. The general administrative body should also hold regular meetings, takes minutes, and communicates relevant information to staff. According to National Accreditation Board, the important duty of tertiary institutions is to search for knowledge either for its own sake or to apply such knowledge to enhance, directly or indirectly, the material well-being, happiness, and comfort of humankind [11]. Based on this tertiary institution such NMTCs are obligated to periodically conduct and publish research to improve in the knowledge level of the institution as well as Ghana as a whole.

\section{RESEARCH METHOD}

The study relied on a quantitative method that helped the researchers to deduce the state of quality assurance in NMTCs in the Upper West Region of Ghana. The reason for adopting a quantitative approach is to help gather in-depth information about quality assurance activities in NMTCs as conjectured by Creswell [16]. The study population entails Health tutors and students in the seven NMTCs in the Upper West Region of Ghana. The accessible population included health tutors who have spent at least one academic year in the institution and health tutors who are members of the quality assurance committee as well as final year students in the institutions studied. We agree with Ryan [17] that students who are important stakeholders in quality assurance policy development and implementation is crucial to be included in any quality assurance study. The sample size of the study was determined as 272 Health tutors and final year students of all the seven health training institutions in the region. This sample size was determined using the Yamane's formula $[n=N / 1+N(\mathrm{e}) 2]$ A census was utilized to choose the colleges (seven in the region), stratified proportionate sampling technique for academic staff (67) and final year students (205), purposive sampling for selecting both staffs (tutors who have adequate knowledge on QA) and students. A structured questionnaire was designed and used for garnering the quantitative data for the study [16]. The three questionnaires designed for the study were pilot tested on a small section of the sample groups to vouch for their validity [18]. After the pilot study, the feedback obtained was used in improving the questionnaires that were finally administered for the full-scale study.

The data collected with the aid of the questionnaire were analyzed using SPSS version 20 and Stata. Descriptive analysis was employed which included mean, standard deviation, and frequency (percentage) to explain the availability of quality assurance policies and their implementation in NMTCs in the Upper West Region, the practice of quality assurance activities (such as quality of infrastructure, the value of academic staff and value of examination). Chi-square was used to explain variations in the magnitude of quality assurance policy implementation in NMTCs in the Upper West Region.

\section{RESULTS AND DISCUSSION}

\subsection{Availability of quality assurance policies in health training facilities}

Quality assurance policies are necessary and serve as standard guidelines for an institution to produce the best nursing and midwifery professional as mandated by these colleges [13]. This section examines the availability of QA policies in NMTCs in the region. The results in Table 1 shows that $34.3 \%$ of health tutors who responded to the question said 'yes' while $41.8 \%$ indicated 'no' to the availability of a QA policy document. 23.9\% of the surveyed tutors did not know whether or not a QA policy was available in the institution in which they work as academic staff. Their views support the findings of Utuka [7] who posited that higher education institutions in Ghana rarely have evidence of approaches on value affirmation methods and the documentation of these in books. However, the findings contradict with WHO's [4] guidelines for nursing and midwifery education institutions which indicated that every NMEI ought to build up their strategies and components to stick to government approaches, and effectively actualize quality assurance systems with persistent checking and evaluation. Wa-NTC $(16.7 \%)$ had the highest assertion by tutors on the availability of QA policy followed by MTC-Jirapa (6.1\%) as shown in Table 2.

Institutionally, only Wa Nursing Training School and Jirapa Midwifery Training School had a policy document for ensuring quality (16.7\% and $6.1 \%$ respectively) as at the period of the project. These findings 
contravene that of Seniwoliba [14] who indicated that aside from the criterion set up by the quality assurance bodies to guarantee quality in advanced education, every college in Ghana has its policies which are internal systems for guaranteeing the satisfaction of its mandate as trustworthy higher education organizations. Table 2 displays the results of individual colleges with regard to QA policy availability.

Table 1. Quality assurance policy implementation level in NMTCs in the Upper West Region

\begin{tabular}{lccc}
\hline & Low (\%) & High (\%) & Total (\%) \\
\hline Quality assurance policy implementation level & 65.6 & 34.4 & 100 \\
\hline Source: Field data (2019) & & &
\end{tabular}

Table 2. Quality assurance policy availability in NMTCs in the Upper West Region

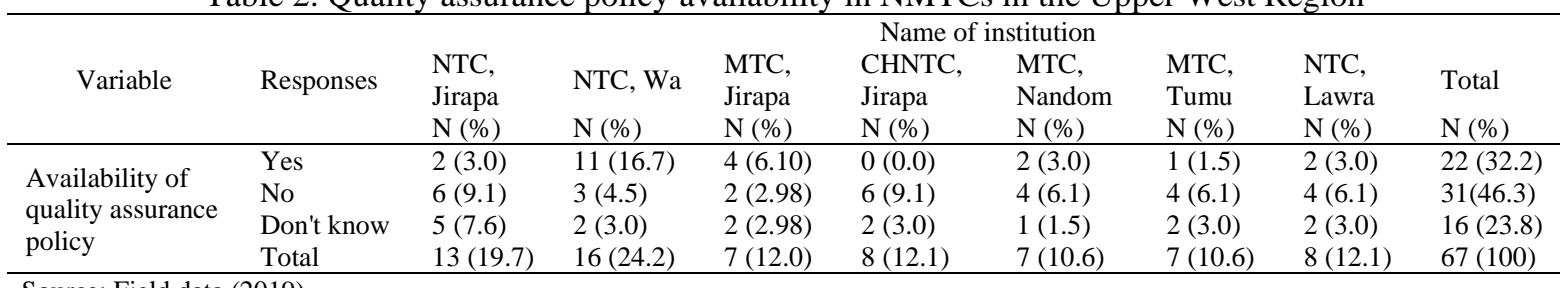

\subsection{Implementation of quality assurance in nursing and midwifery training colleges in the Upper West Region}

Among higher education institutions, one thing is developing a policy and another is ensuring its effective implementation of the policy [4], [19]. Because of this, the WHO outlines key areas for the implementation by NMEIs as stated in the literature review. Statistically from the perspective of health tutors surveyed, the general implementation rate of QA systems in NMTCs in the Upper West Region is low (65.6\%). This result is ascribed to the need for QA approaches in most of these colleges in the region. The findings also indicated that the National Accreditation Board (NAB) has failed in its statutory mandates. The board is mandated to ensure the existence of the functional internal quality assurance unit (IQAU) in schools that are recognized by them, which is a key pointer in surveying the exhibition of an establishment towards organization re-approval and the award of a presidential approval [20]. The health tutors believe that indicators such as good governance, appointment, and/or activation of QA units in the institutions by principals, provision, and/or maintenance of physical facilities, among others are not put in place and hence the low implementation rate.

Among the individual institutions (NMTCs) in the region, NTC-Wa has the highest implementation rate as compared to institutions that have the QA policy (16\%: $\mathrm{p}=0.01)$. Despite the availability of the QA policy document in Jirapa MTC, the implementation of the policy was very low (1.5\%: $\mathrm{p}=0.02)$. Table 3 shows the details of the individual colleges' levels (\%) of QA policy implementation. These findings reiterate the fact that proximity to regulatory bodies has a positive correlation with the availability and implementation of QA policy, Wa NTC being located in the regional capital with the highest proximity to regulatory bodies coupled with high numbers of staffing might be a motivation factor for its ability to implement its QA policies compared to Tumu NTC and Nandom MTC which are sited in the outermost boundaries of the region with inadequate staffing $(\mathrm{p}=0.02)$. This is supported by Seniwoliba and Yakubu [21]; Bank and Popoola [22], as well as Gamage, et al. [6] as they also outlined that staffing and workplaces; physical and money related assets; responsibility and support for quality assurance regulatory bodies are some of the policy implementation challenges in higher education.

Table 3. QA implementation levels by institutions

\begin{tabular}{|c|c|c|c|c|c|}
\hline \multirow{2}{*}{ Name of institution } & \multicolumn{5}{|c|}{ QA implementation by institutions } \\
\hline & $\begin{array}{c}\text { Low } \\
\text { N }(\%)\end{array}$ & $\begin{array}{l}\text { High } \\
\text { N }(\%)\end{array}$ & $\begin{array}{c}\text { Total } \\
\mathrm{N}(\%)\end{array}$ & Chi-square & P-value \\
\hline NTC, Jirapa & $12(17.9)$ & $1(1.5)$ & $13(19.4)$ & \multirow{8}{*}{14.97} & \multirow{8}{*}{0.01} \\
\hline NTC, Wa & $5(7.5)$ & $11(16.4)$ & $16(23.9)$ & & \\
\hline MTC, Jirapa & $5(7.5)$ & $3(4.5)$ & $8(11.9)$ & & \\
\hline CHNTC, Jirapa & $8(11.9)$ & $0(0.0)$ & $8(11.9)$ & & \\
\hline MTC, Nandom & $3(4.5)$ & $4(6.0)$ & $7(10.4)$ & & \\
\hline MTC, Tumu & $5(7.5)$ & $2(3.0)$ & $7(10.4)$ & & \\
\hline NTC, Lawra & $6(9.0)$ & $2(3.0)$ & $8(11.9)$ & & \\
\hline Total & $44(65.6)$ & $23(34.4)$ & $67(100)$ & & \\
\hline
\end{tabular}




\subsubsection{Quality assurance practices in nursing and midwifery training colleges in the upper west region}

This section shows the general institutional QA practiced rate from the perspective of both tutors and students in the Upper West Region.

\section{a. Quality assurance committee/unit}

Some of the variables assessed in the area of practices by NMTCs from the perspective of health tutors and students in the Upper West Region included; the functionality of QA units or committee in the colleges, quality of academic staff, quality of admission process, the value of infrastructure and quality of governance. These according to WHO [3] will create an atmosphere for tutors to give quality training and play their assigned role viably in delivering qualified alumni who will address the issues and desires for society. Positive collaboration between the educator and the student and the aggregate honesty and polished methodology of the scholastic network is expected to yield qualified graduates. Findings indicated that $65.7 \%$ of the surveyed tutors stated 'Yes' for the availability of the QA unit/committee in the colleges. However, the majority $(50.0 \%)$ asserted that these committees are not active and $18.8 \%$ are not certain whether or not these committees are active. In concession with a study conducted in the Northern region by Essel, Boakye-Yiadom, and Mohammed [23] which also revealed that a more prominent number of tutors from the three NMTCs declared the availability of quality assurance unit/committee in their schools. This is also under the WHO recommendation of the selection of a value affirmative committee in charge of auditing internally, watching over, and assessment of QA systems. Granted, tertiary institutions thrive on the committee system [24] and as such, putting in place a QA committee in the Upper West Region is commendable.

However, the inactiveness of the QA committees in the Upper West Region will defeat the objective of monitoring and evaluating the quality of instructing and learning in their respective institutions. The impact will be the production of graduates with low standards of professionalism [25]. Quality of academic Staff value and that of the admission process was high among tutors (66.7\% and $79.1 \%$ respectively). This was not different from the perspective of the students as $84.4 \%$ of the students affirmed the quality of Academic staff to be high. Wa NTC recorded the highest $(21.5 \%: \mathrm{P}=0.03)$ in terms of quality of academic staff while Nandom NTC recoded the least (5.9\%) as seen in Table 4. Staff evaluation is crucial for ensuring the value of training of nurses and birthing attendants [26]. The National Accreditation Board [11] recommends that academic staff must be evaluated especially by students as they are the primary beneficiary of these staff. This is important because students offer the learning challenges from their perspective and this enhances the evaluation of quality [27]. Responses from students regarding staff evaluation revealed that Wa NTC evaluates health tutors once every semester as indicate by NAB. However, students from Jirapa NTC indicated that they do not evaluate academic staff regarding academic staff performance as far as training nurses is a concern. Students from the remaining NMTCs are uncertain about whether or not they evaluate health tutors in their various institutions as presented in Table 5. Table 4 represents responses from health tutors in the Upper West region regarding the conduction and publication of research in their various institutions as recommended by NAB. Findings revealed that no NMTC in the Upper West region fulfills this mandate by the National Accreditation Board [11]. This may be attributed to the lack of participatory governance and the existence of poor communication system between staff and heads in their respective institutions [28].

Table 4. Tutors' responses on research and publication

\begin{tabular}{|c|c|c|c|c|c|c|c|c|}
\hline \multirow[b]{2}{*}{ Variable } & \multirow[b]{2}{*}{ Responses } & \multicolumn{7}{|c|}{ Institutions } \\
\hline & & $\begin{array}{l}\text { NTC, } \\
\text { Jirapa }\end{array}$ & $\begin{array}{c}\text { NTC, } \\
\text { Wa }\end{array}$ & $\begin{array}{l}\text { MTC, } \\
\text { Jirapa }\end{array}$ & $\begin{array}{c}\text { CHNTC, } \\
\text { Jirapa }\end{array}$ & $\begin{array}{c}\text { MTC, } \\
\text { Nandom }\end{array}$ & $\begin{array}{l}\text { MTC, } \\
\text { Tumu }\end{array}$ & $\begin{array}{l}\text { NTC, } \\
\text { Lawra }\end{array}$ \\
\hline Research and publication & Yes & $0.00 \%$ & $6.00 \%$ & $7.50 \%$ & $0.00 \%$ & $1.50 \%$ & $4.50 \%$ & $3.00 \%$ \\
\hline by tutors & No & $19.40 \%$ & $17.90 \%$ & $4.50 \%$ & $11.90 \%$ & $9.00 \%$ & $6.00 \%$ & $9.00 \%$ \\
\hline
\end{tabular}

Source: Field data (2019)

Table 5. Students' responses to tutors' evaluation in NMTCs in the Upper West Region

\begin{tabular}{|c|c|c|c|c|c|c|c|c|}
\hline Variables & $\begin{array}{l}\text { Students' } \\
\text { responses }\end{array}$ & $\begin{array}{l}\text { NTC, } \\
\text { Jirapa }\end{array}$ & $\begin{array}{c}\text { NTC, } \\
\text { Wa }\end{array}$ & $\begin{array}{l}\text { MTC, } \\
\text { Jirapa }\end{array}$ & $\begin{array}{c}\text { Institutions } \\
\text { CHNTC, } \\
\text { Jirapa }\end{array}$ & $\begin{array}{c}\text { MTC, } \\
\text { Nandom }\end{array}$ & $\begin{array}{l}\text { MTC, } \\
\text { Tumu }\end{array}$ & $\begin{array}{l}\text { NTC, } \\
\text { Lawra }\end{array}$ \\
\hline \multirow{2}{*}{ Evaluation of tutors } & Yes & $0.0 \%$ & $20.6 \%$ & $7.4 \%$ & $5.4 \%$ & $4.4 \%$ & $2.5 \%$ & $7.4 \%$ \\
\hline & No & $14.2 \%$ & $1.5 \%$ & $8.3 \%$ & $7.8 \%$ & $2.9 \%$ & $9.3 \%$ & $8.3 \%$ \\
\hline \multirow{3}{*}{$\begin{array}{l}\text { Number of times } \\
\text { evaluation is done } \\
\text { per semester }\end{array}$} & Once & $0.0 \%$ & $34.3 \%$ & $9.1 \%$ & $1.0 \%$ & $7.1 \%$ & $2.0 \%$ & $8.1 \%$ \\
\hline & Twice & $0.0 \%$ & $8.1 \%$ & $5.1 \%$ & $8.1 \%$ & $3.0 \%$ & $0.0 \%$ & $7.1 \%$ \\
\hline & Thrice & $0.0 \%$ & $0.0 \%$ & $1.0 \%$ & $2.0 \%$ & $0.0 \%$ & $3.0 \%$ & $1.0 \%$ \\
\hline
\end{tabular}




\section{b. Quality of governance in NMTCs in the Upper West Region}

In the aspect of governance, $42.9 \%$ of health educators were not fulfilled with the quality of governance and transparency within their institutions. This outlines the loss of confidence of tutors in their institution's leadership. The style of leadership in their various institutions was not up to standard and expectations. Areas of interest were professional staff development programs implementation, accountability, and governance in the schools. These indicated that there is no participatory governance and the existence of a poor communication system between staff and heads in their respective institutions. This is contrary to WHO [4], [29] which indicated that the general administrative body in every NMEI must always hold regular staff meetings, take minutes, and communicate relevant data to staff. This, therefore, point out that there is a poor governance system in NMTCs in the Upper West Region.

\section{c. Quality of infrastructure}

Both students and health tutors were asked whether their colleges ensure the availability of physical structures, well-equipped skill laboratory and whether the skill laboratory is spacious enough for many sessions at a time to ensure the value of instructing and learning. The quality of infrastructure among the NMTCs in the Upper West Region is slightly high as findings indicating $55.2 \%$ for health tutors and $53.2 \%$ for students affirming to this. The highest score was among tutors of the Wa NTC while the lowest was among Lawra NTC as shown in Table 6 and Table 7.

Nandom MTC students were more of the view that their infrastructural quality was very low (2.9\%) while Wa NTC students appreciated the quality of their infrastructure $(20.5 \%)$. This variance between institutions depicts the deficits in infrastructural development in terms of skill laboratories, internet services, lecture halls, and accommodations as indicated in Table 8.

Table 6. Institutional QA implementation/practices

\begin{tabular}{|c|c|c|c|c|c|c|c|c|c|c|}
\hline \multirow[b]{2}{*}{ Variables } & \multirow[b]{2}{*}{ Responses } & \multicolumn{8}{|c|}{ Name of Institution } & \multirow[b]{2}{*}{ P-value } \\
\hline & & $\begin{array}{l}\text { NTC, } \\
\text { Jirapa } \\
\text { N (\%) } \\
\end{array}$ & $\begin{array}{l}\text { NTC, } \\
\text { Wa } \\
\text { N }(\%) \\
\end{array}$ & $\begin{array}{l}\text { MTC, } \\
\text { Jirapa } \\
\text { N }(\%)\end{array}$ & $\begin{array}{c}\text { CHNTC, } \\
\text { Jirapa } \\
\text { N }(\%)\end{array}$ & $\begin{array}{c}\text { MTC, } \\
\text { Nandom } \\
\text { N (\%) }\end{array}$ & $\begin{array}{l}\text { MTC, } \\
\text { Tumu } \\
\text { N }(\%)\end{array}$ & $\begin{array}{l}\text { NTC, } \\
\text { Lawra } \\
\text { N }(\%)\end{array}$ & $\begin{array}{l}\text { Total } \\
\mathrm{N}(\%)\end{array}$ & \\
\hline \multirow{4}{*}{$\begin{array}{l}\text { Availability of } \\
\text { quality } \\
\text { assurance } \\
\text { policy }\end{array}$} & Yes & $2(3.0)$ & $11(16.7)$ & $4(6.10$ & $0(0.0)$ & $2(3.0)$ & $1(1.5)$ & $2(3.0)$ & $22(33.3)$ & \multirow[t]{4}{*}{0.05} \\
\hline & No & $6(9.1)$ & $3(4.5)$ & $1(1.5)$ & $6(9.1)$ & $4(6.1)$ & $4(6.1)$ & $4(6.1)$ & $28(42.4)$ & \\
\hline & Don't know & $5(7.6)$ & $2(3.0)$ & $2(3.0)$ & $2(3.0)$ & $1(1.5)$ & $2(3.0)$ & $2(3.0)$ & $16(24.4)$ & \\
\hline & Total & $13(19.7)$ & $16(24.2)$ & $7(10.6)$ & $8(12.1)$ & $7(10.6)$ & $7(10.6)$ & $8(12.1)$ & $66(100)$ & \\
\hline \multirow{4}{*}{$\begin{array}{l}\text { Availability of } \\
\text { QA } \\
\text { committee/unit }\end{array}$} & Yes & $7(10.4)$ & 13(19.4) & $5(7.5)$ & $3(4.5)$ & $7(10.4)$ & $2(3.0)$ & $7(10.4)$ & $44(65.7)$ & \multirow[t]{4}{*}{0.04} \\
\hline & No & $6(9.0)$ & $2(3.0)$ & $1(1.5)$ & $4(6.0)$ & $0(0.0)$ & $4(6.0)$ & $1(1.5)$ & $18(26.9)$ & \\
\hline & Don't know & $0(0.0)$ & $1(1.5)$ & $2(3.0)$ & $1(1.5)$ & $0(0.0)$ & $1(1.5)$ & $0(0)$ & $5(7.5)$ & \\
\hline & Total & $13(19.4)$ & $16(23.9)$ & $8(11.9)$ & $8(11.9)$ & $7(10.4)$ & $7(10.4)$ & $8(11.9)$ & $67(100)$ & \\
\hline \multirow{4}{*}{$\begin{array}{l}\text { Is QA unit } \\
\text { active }\end{array}$} & Yes & $0(0.0)$ & $8(16.7)$ & $2(4.2)$ & $0(0.0)$ & $4(8.3)$ & $0(0.0)$ & $1(2.1)$ & $15(31.3)$ & \multirow[t]{4}{*}{0.00} \\
\hline & No & $6(12.5)$ & $4(8.3)$ & $1(2.1)$ & $3(6.3)$ & $2(4.2)$ & $2(4.2)$ & $6(12.5)$ & $24(50.0)$ & \\
\hline & Don't know & $1(2.1)$ & $1(2.1)$ & $4(8.3)$ & $0(0.0)$ & $1(2.1)$ & $2(4.2)$ & $0(0)$ & $9(18.8)$ & \\
\hline & Total & $7(14.6)$ & $13(27.1)$ & $7(14.6)$ & $3(6.3)$ & $7(14.6)$ & $4(8.3)$ & $7(14.6)$ & $48(100)$ & \\
\hline \multirow{3}{*}{$\begin{array}{c}\text { Quality of } \\
\text { academic staff }\end{array}$} & Low & $9(13.6)$ & $3(4.5)$ & $1(1.5)$ & $6(9.1)$ & $1(1.5)$ & $0(0.0)$ & $2(3.0)$ & $22(33.3)$ & \multirow[t]{3}{*}{0.02} \\
\hline & High & $4(6.1)$ & $12(18.2)$ & $7(10.6)$ & $2(3.0)$ & $6(9.1)$ & $7(10.6)$ & $6(9.1)$ & $44(66.7)$ & \\
\hline & Total & 13(19.7) & $15(22.7)$ & $8(12.1)$ & $8(12.1)$ & $7(10.6)$ & $7(10.6)$ & $8(12.1)$ & $66(100)$ & \\
\hline \multirow{3}{*}{$\begin{array}{l}\text { Quality of } \\
\text { admission } \\
\text { processes }\end{array}$} & Low & $8(11.9)$ & $1(1.5)$ & $2(3.0)$ & $2(3.0)$ & $0(0.0)$ & $0(0.0)$ & $1(1.5)$ & $14(20.9)$ & \multirow[t]{3}{*}{0.00} \\
\hline & High & $5(7.5)$ & $15(22.4)$ & $6(9.0)$ & $6(9.0)$ & $7(10.4)$ & $7(10.4)$ & $7(10.4)$ & $53(79.1)$ & \\
\hline & Total & $13(19.4)$ & $16(23.9)$ & $8(11.9)$ & $8(11.9)$ & $7(10.4)$ & $7(10.4)$ & $8(11.9$ & $67(100)$ & \\
\hline \multirow{3}{*}{$\begin{array}{l}\text { Quality of } \\
\text { infrastructure }\end{array}$} & Low & $10(15.2)$ & $3(4.5)$ & $0(0.0)$ & $4(6.1)$ & $5(7.6)$ & $1(1.5)$ & $7(10.6)$ & $30(44.8)$ & \multirow[t]{3}{*}{0.00} \\
\hline & High & $2(3.0)$ & 13(19.7) & $8(12)$. & $4(6.1)$ & $2(3.0)$ & $6(9.1)$ & $1(1.5)$ & $37(55.2)$ & \\
\hline & Total & $12(18.2)$ & $16(24.2)$ & $8(12.1)$ & $8(12.1)$ & $7(10.6)$ & $7(10)$. & $8(12.1)$ & $66(100)$ & \\
\hline \multirow{3}{*}{$\begin{array}{l}\text { Quality of } \\
\text { examination }\end{array}$} & Low & 12(17.9) & $2(3.0)$ & $1(1.5)$ & $4(6.0)$ & $1(1.5)$ & $0(0.0)$ & $2(3.0)$ & $22(32.8)$ & \multirow[t]{3}{*}{0.00} \\
\hline & High & $1(1.5)$ & $14(20.9)$ & $7(10.4)$ & $4(6.0)$ & $6(9.0)$ & $7(10.4)$ & $6(9.0)$ & $45(67.2)$ & \\
\hline & Total & $13(19.4)$ & $16(23.9)$ & $8(11.9)$ & $8(11.9)$ & $7(10.4)$ & $7(10.4)$ & $8(11.9)$ & $67(100)$ & \\
\hline \multirow{3}{*}{$\begin{array}{l}\text { Quality of } \\
\text { governance }\end{array}$} & Low & $10(15.9)$ & $5(7.9)$ & $3(4.8)$ & $7(11.1)$ & $1(1.6)$ & $5(7.9)$ & $5(7.9)$ & $36(57.1)$ & \multirow[t]{3}{*}{0.002} \\
\hline & High & $0(0.0)$ & $11(17.5)$ & $5(7.9)$ & $1(1.6)$ & $5(7.9)$ & $2(3.2)$ & $3(4.8)$ & $27(42.9)$ & \\
\hline & Total & $10(15.9)$ & $16(25.4)$ & $8(12.7)$ & $8(12.7)$ & $6(9.5)$ & $7(11.1)$ & $8(12.7)$ & $63(100.0)$ & \\
\hline
\end{tabular}

Source: Field data (2019) 
Table 7. Quality assurance activities, students

\begin{tabular}{|c|c|c|c|c|c|c|c|c|c|c|}
\hline $\begin{array}{c}\text { Variables } \\
\text { (Quality assurance } \\
\text { indicators-students) }\end{array}$ & & $\begin{array}{l}\text { NTC, } \\
\text { Jirapa }\end{array}$ & $\begin{array}{l}\text { NTC, } \\
\text { Wa }\end{array}$ & $\begin{array}{l}\text { MTC, } \\
\text { Jirapa }\end{array}$ & $\begin{array}{l}\text { CHNTC, } \\
\text { Jirapa }\end{array}$ & $\begin{array}{l}\text { MTC, } \\
\text { Nandom }\end{array}$ & $\begin{array}{l}\text { MTC, } \\
\text { Tumu }\end{array}$ & $\begin{array}{l}\text { NTC, } \\
\text { Lawra }\end{array}$ & Total & P-value \\
\hline \multirow{3}{*}{$\begin{array}{l}\text { Quality of } \\
\text { infrastructure }\end{array}$} & No & 19 & 3 & 10 & 18 & 9 & 12 & 25 & 96 & \multirow{3}{*}{0.00} \\
\hline & Yes & 10 & 42 & 22 & 9 & 6 & 12 & 8 & 109 & \\
\hline & Total & 29 & 45 & 32 & 27 & 15 & 24 & 33 & 205 & \\
\hline \multirow{3}{*}{$\begin{array}{l}\text { Quality of } \\
\text { accommodation }\end{array}$} & No & 20 & 45 & 23 & 18 & 13 & 14 & 32 & 165 & \multirow{3}{*}{0.00} \\
\hline & Yes & 9 & 0 & 9 & 9 & 2 & 10 & 1 & 40 & \\
\hline & Total & 29 & 45 & 32 & 27 & 15 & 24 & 33 & 205 & \\
\hline \multirow{3}{*}{$\begin{array}{l}\text { Quality of academic } \\
\text { staff }\end{array}$} & No & 4 & 1 & 3 & 7 & 3 & 7 & 7 & 32 & \multirow{3}{*}{0.03} \\
\hline & Yes & 25 & 44 & 29 & 20 & 12 & 17 & 26 & 173 & \\
\hline & Total & 29 & 45 & 32 & 27 & 15 & 24 & 33 & 205 & \\
\hline \multirow{3}{*}{$\begin{array}{l}\text { Quality of student } \\
\text { academics }\end{array}$} & No & 18 & 13 & 13 & 16 & 9 & 11 & 16 & 96 & \multirow{3}{*}{0.07} \\
\hline & Yes & 11 & 32 & 19 & 11 & 6 & 13 & 17 & 109 & \\
\hline & Total & 29 & 45 & 32 & 27 & 15 & 24 & 33 & 205 & \\
\hline \multirow{5}{*}{$\begin{array}{l}\text { Quality of } \\
\text { examination }\end{array}$} & No & 12 & 20 & 15 & 15 & 12 & 7 & 16 & 97 & \multirow{5}{*}{0.09} \\
\hline & Yes & 17 & 25 & 17 & 12 & 3 & 17 & 17 & 108 & \\
\hline & Total & 29 & 45 & 32 & 27 & 15 & 24 & 33 & 205 & \\
\hline & Yes & 10 & 30 & 16 & 7 & 5 & 8 & 3 & 79 & \\
\hline & Total & 29 & 45 & 32 & 27 & 15 & 24 & 33 & 205 & \\
\hline
\end{tabular}

Source: Field data (2019)

Table 8. Quality of infrastructure in NMTCs: Students

\begin{tabular}{|c|c|c|c|}
\hline Variable & Responses & $\begin{array}{c}\text { Tutors } \\
n=67\end{array}$ & $\begin{array}{c}\text { Students } \\
\mathrm{n}=207\end{array}$ \\
\hline \multirow{2}{*}{ Physical facilities available and maintained } & Yes & 79.1 & 58.5 \\
\hline & No & 20.9 & 41.5 \\
\hline \multirow{2}{*}{ Skill laboratory is adequately spaced } & Yes & 46.3 & 35.1 \\
\hline & No & 53.7 & 64.9 \\
\hline \multirow{2}{*}{ The laboratory is well equipped } & Yes & 79.1 & 57.6 \\
\hline & No & 20.9 & 42.4 \\
\hline \multirow{2}{*}{ Lecture halls are large and well ventilated } & Yes & 58.2 & 36.1 \\
\hline & No & 41.8 & 63.9 \\
\hline \multirow{2}{*}{ Availability of internet service in school } & Yes & 71.6 & 79.5 \\
\hline & No & 28.4 & 20.5 \\
\hline \multirow{2}{*}{ Availability of internet at all time } & Yes & 40.3 & 16.1 \\
\hline & No & 35.8 & 32.2 \\
\hline \multirow{2}{*}{ Is the school library well stocked with up-to-date books for easy referencing? } & Yes & 46.3 & 34.1 \\
\hline & No & 53.7 & 65.9 \\
\hline \multirow{2}{*}{ Is the library spacious for studies? } & Yes & 37.3 & 58 \\
\hline & No & 62.7 & 42 \\
\hline \multirow{2}{*}{ The library is readily accessible by students and tutors at all time } & Yes & 74.6 & 63.4 \\
\hline & No & 25.4 & 36.6 \\
\hline \multirow{2}{*}{ The school IT laboratory is large with adequate computers } & Yes & 44.8 & 32.1 \\
\hline & No & 55.2 & 67.9 \\
\hline \multirow{2}{*}{ Availability of audiovisual devices } & Yes & 52.2 & 27.3 \\
\hline & No & 47.8 & 72.7 \\
\hline
\end{tabular}

Source: Field data (2019)

Data shortage and poor network connections were some major challenges confronted by the tutors in terms of internet connectivity. The availability of a good computer laboratory and internet services were also assessed. Uniformly majority of tutors $(55.2 \%)$ and students $(67.6 \%)$ were of the view that their IT laboratories were not well spaced and equipped with computers to encourage instructing and learning. This translated to the accessibility of internet services for instructing and learning where the majority of tutors $(71.6 \%)$ and students $(79.5 \%)$ indicated that there is internet service available in their colleges, however, there were disparities in the accessibility to the service, $40.3 \%$ of health tutors indicated having access to the internet services as compared with $16.1 \%$ of the students. Reasons given included poor network (18\%), shortage of bundle $(5.4 \%)$, narrow coverage of internet services (5.4\%), IT officer shutting it down (1.5\%) among others, and this does not differ from the responses of some tutors who did not get access to the internet services. Yet, these are resources that must be present for effective teaching and learning by both tutors and students, yet, they are not [4], [29]. The inaccessibility of these facilities by students will affect their ability to take control and coordinate their claim learning encounters and personal studies instead of being over-reliance on tutors. Furthermore, the more students are comfortable with teaching and learning facilities, the more they are encouraged to learn on their own, and the better they become as students [19], [24]. 
The majority of the respondents; tutors $(53.7 \%)$ and students $(64.9 \%)$ indicated a lack of adequate space in their skill laboratories although, these laboratories are well equipped. The displeasure by both tutors and students were statistically significant $(\mathrm{p}=0.00)$, the accessibility of satisfactory hardware for instructing and learning will enhance the confidence level of students and tutors in handling medical condition, due to prior first-hand clinical practices. About $41 \%$ of students asserted that their schools do not provide and/or maintain physical infrastructure as against $20.9 \%$ of tutors. A difference of $20.1 \%$ is significant indicating a disparity between access by tutors to infrastructure as against that of students $(\mathrm{P}=0.00)$. This will impact teaching and learning as denial to resources, is denial to knowledge acquisition. A conducive atmosphere enhances quality instructing and learning for both tutors and students respectively, but in this current study majority of the tutors $(58.2 \%)$ agreed that the lecture halls were spacious and well ventilated for instructing and learning, but contrary to that were the views of the students who are the direct users of the facility, majority $(63.9 \%)$ disagreed. Indicating that lecture halls were too small and poorly ventilate considering their number per class.

A poorly ventilated atmosphere creates fatigue and stress therefore impacting the value of instructing and learning. It also prone the occupants to diverse public health communicable disease such as meningitis and tuberculosis that comes with such unfriendly conditions especially in the warm season with overcrowding. In Table $9,68.8 \%$ of the students are accommodated by their respective schools. Meanwhile, $49.3 \%$ of them are not satisfied with the conditions of the hostels the schools provide for them because of poor ventilation and lighting, congestion, a distance far away from campus, and lack of maintenance by management. The remaining $31.2 \%$ of students are not provided with accommodation and hence students sort this by themselves. Figure 4.5 depicts that students of Wa NTC are not provided with any form of hostel facility by the school, they solely cater for themselves as far as accommodation is concerned while Lawra NTC can provide accommodation for $42.4 \%$ of her students' population. The poor students' accommodation may also have a negative impact on their academic performance [5], [19], [30].

The availability of audiovisual devices for teaching and learning was perceived differently by tutors and students. The health tutors $(52.2 \%)$ were of the view that audio-visuals (e.g., projectors and public address systems) for teaching and learning were adequately provided as against $72.7 \%$ of students who said the audiovisuals were not adequately provided.

Table 9. Quality assurance accommodation: Students

\begin{tabular}{lccc}
\hline Quality assurance accommodation & Yes $(\%)$ & No $(\%)$ & Total (\%) \\
\hline Availability of hostel facility & 68.8 & 31.2 & 100 \\
Satisfaction with the hostel facility & 19.5 & 48.3 & 68.8 \\
\hline Source: Field data (2019) & & &
\end{tabular}

Table 10. Availability of accommodation facility for students in the various MNTC, U/W/R

\begin{tabular}{ccc}
\hline Availability of hostel facility & Yes $(\%)$ & No $(\%)$ \\
\hline NTC, Jirapa & 100 & 0 \\
NTC, Wa & 0 & 100 \\
MTC, Jirapa & 100 & 0 \\
CHNTC, Jirapa & 100 & 0 \\
MTC, Nandom & 100 & 0 \\
MTC, Tumu & 100 & 0 \\
NTC, Lawra & 42 & 57 \\
\hline
\end{tabular}

Source: Field data (2019)

\section{CONCLUSION}

This study provided shreds of evidence regarding the lack of QA activities as well as factors that affect QA in some NMTCs in Ghana. The majority (5 out of 7 NMTCs) of the institution had no Quality Assurance policy document. The study's findings revealed that these institutions had quality assurance units/committees that are inactive due to the absence of an operational document that will guide the operations of the committee/unit. Internal quality practices in relation to governance, accountability, and transparency were low among health tutors meanwhile internal quality to promote staff professional development was high and students attested to the high value of academic staff. Despite having highly qualified academic staff, most NMTCs in the region do not conduct staff evaluation. Periodic staff meetings are rarely organized for tutors to discuss matters regarding activities towards the quality training of nurses and midwives in the region. This is partly related to the lack of participatory governance and the existence of poor communication system between staff and heads in their respective institutions. This study recommends that there is a need for managers of 
Health Training Institutions (HTIs) to ensure the formulation and implementation of QA policy documents in their respective colleges. Also, heads (Principals) 11 of NMTCs in the Upper West Region and Ghana as a whole should ensure the formation and functioning of QA units in their various institutions. These units should be empowered and allowed by the heads of the institutions to function as per recommendations by the regulatory bodies to support to ensure quality training of nurses and midwives.

\section{REFERENCES}

[1] P. Materu, Higher education quality assurance in Sub-Saharan Africa: status, challenges, opportunities and promising practices. World Bank Working Paper No. 124, Africa Human Development Series. Washington, DC: World Bank, 2007.

[2] World Health Organization, A guide to nursing and midwifery education standards. World Health Organization. Regional Office for the Eastern Mediterranean. EMRO Publications, 2015. [Online]. Available: https://apps.who.int/iris/handle/10665/195726.

[3] World Health Organization, "Quality assurance and accreditation of nursing and midwifery educational institutions," WHO Regional Office for South-East Asia, 2008. [Online]. Available: https://apps.who.int/iris/handle/10665/205715.

[4] World Health Organization, "Guidelines on quality assurance and accreditation of nursing and midwifery educational institutions," WHO Regional Office for South-East Asia, 2010. [Online]. Available: https://apps.who.int/iris/handle/10665/205195.

[5] J. W. Boateng, "Barriers to Internal Quality Assurance in Ghanaian Private Tertiary Institutions," Research on Humanities and Social Sciences, vol. 4, no. 2, pp. 1-9, 2014.

[6] K. A. A. Gamage, R. G. G. Pradeep, V. Najdanovic-Visak, and N. Gunawardhana, "Academic Standards and Quality Assurance: The Impact of COVID-19 on University Degree Programs," Sustainability, vol. 12, no. 10032, pp. 1-14, 2020.

[7] G. Utuka, "Quality assurance in higher education: Comparative analysis of provisions and practices in Ghana and New Zealand," Doctoral Thesis, Victoria University of Wellington, 2012.

[8] J. Alabi, G. Alabi, R. Adjei, P. Dzandu, G. Utuka, and A. Munkaila, Quality Assurance in Ghanaian Higher Education Institutions: Opportunities and Constraints. Senegal: CODESRIA, 2018.

[9] C. Böhmig, Ghanaian nurses at a crossroads Managing expectations on a medical ward. Leiden: African Studies Centre, 2010.

[10] S. Adu-Gyamfi and E. Brenya, "Nursing in Ghana: A Search for Florence Nightingale in an African City," International Scholarly Research Notices, vol. 2016, 2016, doi: 10.1155/2016/9754845.

[11] National Accreditation Board, Tertiary institutions (establishment and accreditation) regulations, 2010 (L.I. 1984). Accra: Ministry of Education, 2010.

[12] European Association for Quality Assurance in Higher Education Area, Standards and Guidelines for Quality Assurance in the European Higher Education Area. Brussels: EURASHE, 2015.

[13] S. Okae Adjei," Quality Assurance Practices in Ghanaian Polytechnics: The Case of Koforidua Polytechnic," Interdisciplinary Journal of Contemporary Research in Business, vol. 4, pp. 293-299, 2012.

[14] A. Seniwoliba, "Academic Quality Assurance Practices in Ghanaian Public Universities: Experience from University for Development Studies," Global Educational Research Journal, vol. 10, no. 16, pp. 2331-2339, 2014.

[15] F. Ansah, P. Swanzy, and H. P. Nudzor, "Balancing the focus of Quality Assurance Frameworks of Higher Education Institutions in Africa: A Ghanaian Context," in S. L. Renes, Ed., Global Voices in Higher Education. IntechOpen, 2017, doi: 10.5772/intechopen.68665.

[16] J. W. Creswell, Research design: qualitative, quantitative, and mixed methods approach, 14th ed. USA: SAGE Publications, 2014.

[17] T. Ryan, "Quality Assurance in Higher Education: A Review of Literature," Higher Learning Research Communications, vol. 5, no. 4, 2015, doi: 10.18870/hlrc.v5i4.257.

[18] A. L. Whitehead, S. A. Julious, C. L. Cooper, and M. J. Campbell, "Estimating the Sample Size for a Pilot Randomised Trial to Minimise the Overall Trial Sample Size for the External Pilot and Main Trial for a Continuous Outcome Variable," Statistical Methods in Medical Research, vol. 25, no. 3, pp. 1057-1073, 2016.

[19] J. Maina, and J. Y. Aji, "Influence of accommodation on the academic performance of architecture students," Built Environment Journal, vol. 14, no. 2, pp. 47-50, 2017.

[20] National Academy of Sciences, The Future of Nursing: Leading Change, Advancing Health. United States of America: National Academy Press, 2011.

[21] J. A. Seniwoliba and R. N. Yakubu, "An analysis of the quality assurance policies in a Ghanaian University," Academic Journals, vol. 18, pp. 231-239, 2015.

[22] C. M. V. Bank and B. A. Popoola, "A Theoretical Framework of Total Quality Assurance in a University of Technology," Academic Journal of Interdisciplinary Studies, vol. 3, no. 4, pp. 401-408, 2014.

[23] H. B. Essel, M. Boakye-Yiadom, and S. Mohammed, "Internal Quality Assurance Practices of Nursing and Midwifery Training Colleges and the Role of Regulatory Bodies: The Perspectives of Health Tutors," Journal of Nursing Education and Practice, vol. 8, pp. 68-75, 2018.

[24] G. K. Anane and M, Addaney, "Managing Quality Assurance in Higher Education: The Case of the University of Energy and Natural Resources, Ghana," Journal of Education and Practice, vol. 7, no. 22, pp. 41-46, 2016. 
[25] M. Seyfried and P. Pohlenz, "Assessing quality assurance in higher education: quality managers' perceptions of effectiveness," European Journal of Higher Education, vol. 8, no. 3, pp. 258-271, 2018.

[26] T. Moradi, M. A. Mehraban. and M. Moeni, "Comparison of the Perceptions of Managers and Nursing Staff toward Performance Appraisal," Iranian Journal of Nursing and Midwifery Research, vol. 22, no. 2, pp. 128-134, 2017.

[27] S. Warman, "Challenges and issues in the evaluation of teaching quality: how does it affect teachers' professional practice? A UK perspective," Journal of Veterinary Medical Education, vol. 1, no. 1, pp. 1-7, 2015.

[28] H. J. Machumu and S. H. Kisanga, "Quality Assurance Practices in Higher Education Institutions: Lesson from Africa," Journal of Education and Practice, vol. 5, no. 16, pp. 144-156, 2014.

[29] R. Mahbub, "Quality Assurance for Higher Education: Challenges in Sustaining Continuous Quality Improvement for Malaysian Universities," Proceedings of INTED2017 Conference, Valencia, Spain, 2017, doi: 10.21125/inted.2017.1214.

[30] B. O. Owolabi, "The Effects of Students' Housing on Academic Performance at the University of Ibadan," International Journal of Scientific \& Engineering Research, vol. 6, no. 3, pp. 1118-1132, 2015. 